\title{
Risk Factor History
}

National Cancer Institute

\section{Source}

National Cancer Institute. Risk Factor History. NCI Thesaurus. Code C157153.

A record of an individual's attribute, characteristic or exposure that increases the

likelihood of developing a disease or injury. (WHO) 